\title{
高松地域の不圧地下水の水位・水質に 及ぼす灌溉の影響 \\ EFFECTS OF IRRIGATION ON LEVEL AND QUALITY OF UNCONFINED GROUNDWATER IN TAKAMATSU AREA
}

\author{
河原能久 1 ・渡邊健一 2 ・橋本美智子 3 \\ Yoshihisa KAWAHARA, Kenichi WATANABE and Michiko HASHIMOTO \\ 1 フェロー会員 工博 香川大学教授 工学部安全システム建設工学科（テ761-0396 高松市林町 2217-20) \\ 2 学生会員 香川大学大学院工学研究科安全システム建設工学専攻 (テ761-0396 高松市林町 2217-20) \\ 3 学生会員 香川大学工学部安全システム建設工学科（テ761-0396 高松市林町 2217-20）
}

\begin{abstract}
Extensive field measurement of groundwater level and quality was carried out three times in 2002 at sixty five stations in Takamatsu area to clarify the effects of irrigation on the unconfined groundwater. Continuous measurement of groundwater level has also been made at seven stations in addition to the continuous measurement by the public sectors. It is found that the water level gradually increases in the irrigation period with the contours of water level running nearly parallel to those of topography. The rainfall and the pumping up have influence of the change in water level. The $\mathrm{pH}$ of groundwater is found to slightly increase in the irrigation season while Stiff diagrams and the cluster analysis demonstrate that the water quality can be classified into four groups and that the groundwater quality mostly remains unchanged. Nitrate nitrogen of unconfined water at a few locations has exceeded the environmental standard, which may have come from the overuse of fertilizer. Some wells in the coastal region have shown the effects of seawater intrusion.
\end{abstract}

Key Words : unconfined groundwater, water level, water quality, irrigation, field measurement, Takamatsu

\section{1. はじめに}

香川県では, 多数の溜池の造成に代表されるよう に，昔から水資源の有効利用が図られてきた. 1974 年に吉野川から香川用水を導入し水事情は画期的 に改善された。しかし，その後における水利用の形 態の変化や農地の宅地への転用などで水循環系は 変化してきている. このような変化を背景にして, 健全な水循環系の保全を図りながら水資源の確保 や有效利用を進めることが，高松地域の緊急の課題 となっている.

高松地域の不圧地下水の水位については, 東京教 育大学 ${ }^{1)}$ が平野部において大規模な調查を行ってい る. また, 新見による湧水の分布と涌出量の調查 ${ }^{2}$, 国土交通省や道路公団による高速道路の建設の影 響を検討するための地下水位と水質の調查などが

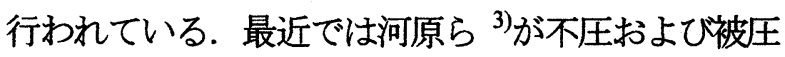
地下水の水位や水質の調查と既存のデータの整理 を行っている. しかし，不圧地下水に影響を及ぼす
メカニズムにまで言及している研究は数少ない.

ところで，香川用水は早明浦ダムによって新たに 開発された水量のうち, 年間 2 億 4,700 万 $\mathrm{m}^{3}$ を香川 県内に導水している. その年間水量の内訳は農業用 水が 1 億 500 万 $\mathrm{m}^{3}$, 水道用水が 1 億 2,200 万 $\mathrm{m}^{3}$, 工 業用水が 2,000 万 $\mathrm{m}^{3}$ である. 農業用水としての導水 量は, 灌溉期に平均で $8.0 \mathrm{~m}^{3} / \mathrm{s}$, 最大 $11.3 \mathrm{~m}^{3} / \mathrm{s}$, 非灌 溉期に平均で $1.0 \mathrm{~m}^{3} / \mathrm{s}$, 最大 $1.5 \mathrm{~m}^{3} / \mathrm{s}$ となっている. 香川用水の導入により農業が安定したことは言う までもないが，地下水の水位や水質に与えた影響は 明らかでなく，水循環系での役割を明らかにするこ とが必要であると考えられる.

本研究は, 灌溉開始前後での地下水の水位, 水質 を観測し，灌溉の地下水に及ぼす影響を把握するこ とを目的としている. また，香川用水の導水前と現 在の地下水の水位を比較することで, 香川用水の導 入により地域の地下水がどのように変化したかを 推測する．なお，地下水の水質に及ぼす施肥や土地 利用の影響を調べた研究は多数あるが例えば ${ }^{4,5}$, 灌 溉の影響を論じた研究は限られているの。 


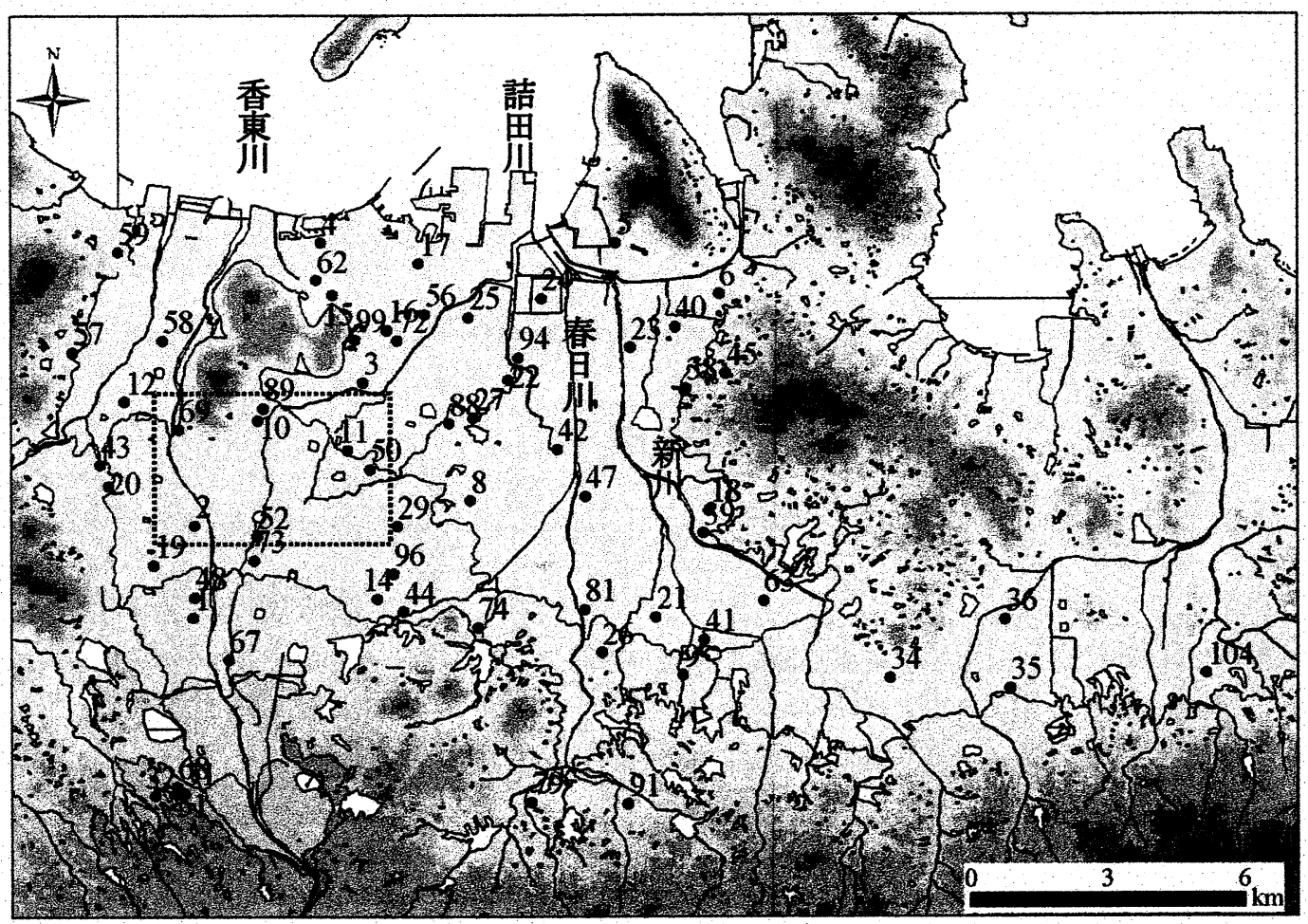

図-1 高松地域の地形と一斉観測を行った井戸の位置

以下では，まず，観測地域の地質の概要，観測内 容を説明する. 次に，地下水の水位の測定結果と考 察, 続いて水質分析の結果と考察を述べる.

\section{2. 観測地域と観測項目}

\section{（1）高松地域の地形・地質の概要}

高松平野は，西部を流れる香東川により形成され た扇状地，東部の春日川，新川等による汇濫平野， および河口部の三角州からなる海岸平野から形成さ れている (図-1 を参照)。香東川右岸の扇状地には 多数の旧河道跡や涌水が存在している.

地質は，上位から沖積層（砂碟，砂層中に粘土・ シルトが不規則に重なる), 三豊層, 基盤 (花崗岩類) に大別される．沖積層と三豊層との境界には細粒分 が卓越した層が広く広がっており，難透水層となっ ている. 上部の帯水層の厚さは地表加深度 $20 \mathrm{~m}$ 程 度であり，そこに多数の浅井戸が設置されている. また, 三豊層中の帯水層は深度 $40 \mathrm{~m} \sim 100 \mathrm{~m}$ 程度で あり，その地下水は被圧状態となっている.

\section{（2）観測の概要}

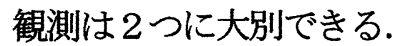

1つめの観測は，不圧地下水の水位と水質の空間 的な分布を把握することを目的とした一斉測水及び 採水した地下水の水質分析である. 民家や学校の管
理する浅井戸 65 箇所において行った. 観測井戸の位 置を図-1に示寸. 観測は, 2001 年 3 月から 3 ケ月に 1 回の間隔で行っているが, 本論文で使用するデー 夕は 2002 年の(1)6月 5, 7 日 (灌溉前)，(26月 26,

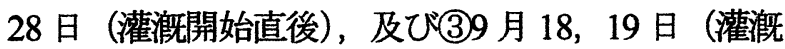
期後半) に測定されたものである. 観測項目と使用 機器は以下のようである.

(1) 地下水位：井戸枠から地下水面までの深さ (YAMAYO ミリオン水位計)

(2) 地下水の水質 (現場) : 水温, $\mathrm{pH}$, 電気伝導度 （堀場製作所 D-24）

(3) 地下水の水質 (持ち帰り分析) : 各種イオン（島 津製作所イオンクロマトグラフィーPIA-1000)

2つめの観測は，特定の地点における水位の時間 的な変動を捉えることを目的とした連続観測である. 7 箇所の井戸にデータロガー付き水位計（光進電気 工業 MC-1100W）を設置し 1 時間間隔で測定した. 観測期間は 2002 年 6 月 1 日以降であり, 現在も観測 を継続している．また，国土父通省香川工事事務所 による連続観測結果も入手させていただいた．本論 文では取得したデータの一部を示すが，それらの観 測地点の位置は図-2に記されている. 図-2は, 図-1 の四角の枠について，土地分類図 ${ }^{7}$ 上に観測地点を プロットしたものである. 多くの観測地点が旧河道 周辺に位置している. 


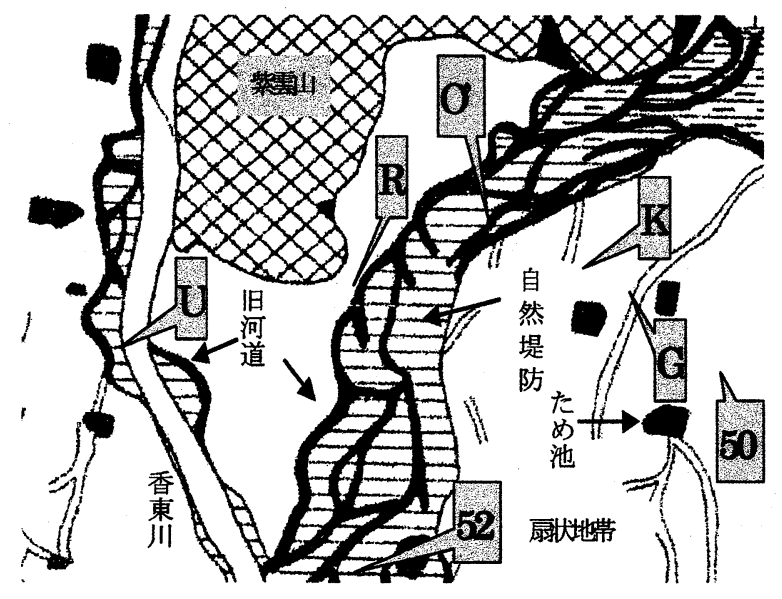

図-2 連続観測地点の位置と土地分類

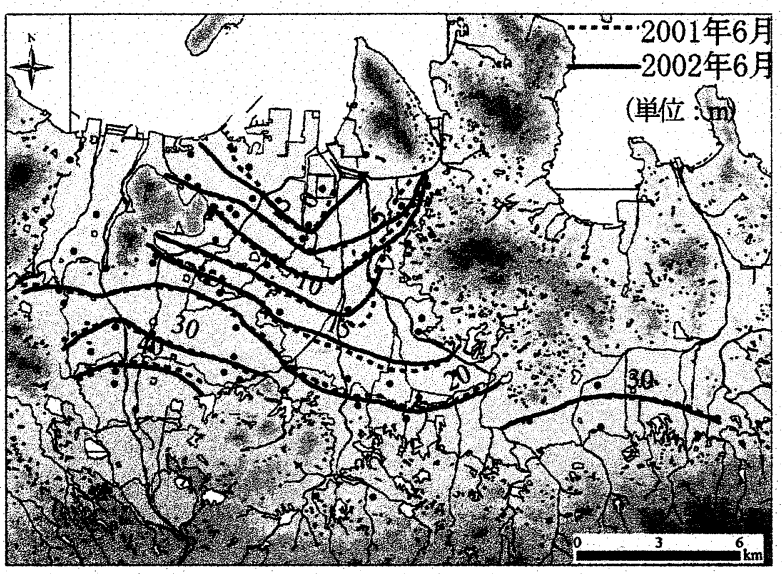

図-4 地下水分布の比較（2001 年 6 月と 2002 年 6 月）

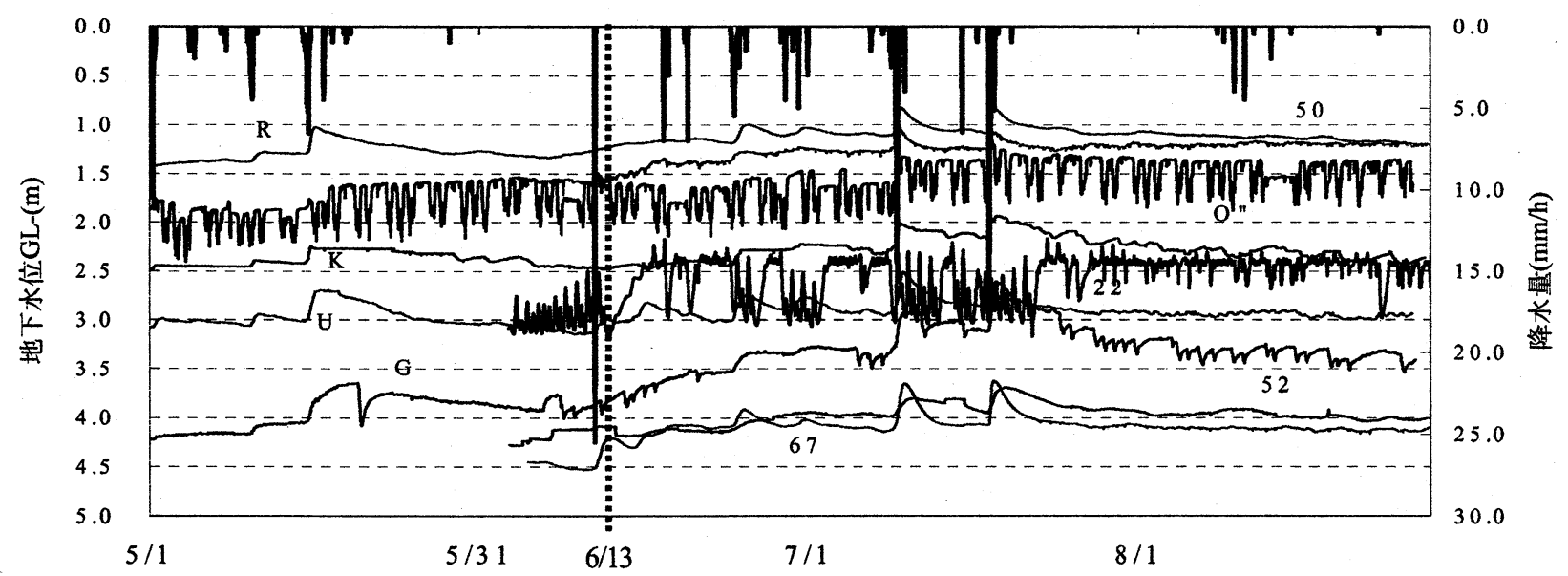

图-3 地下水位の連続観測結果

\section{3. 钼測結果と考察}

\section{(1) 地下水の水位}

高松地域の地下水位の時間的な変動を知るために, 2002 年 5 月はじめから 9 月上旬にかけての水位の連 続観測結果と降水量を図-3に示している. 図中の左 の縦軸は地表面から地下水面までの深さを示してい

る. この図より, 次のことがわかる.

(1) 当該地域の多くの地点では6月13日から灌溉用 水が配水されたが, それ以降地下水位はゆるや かに上昇した。

(2) 井戸あるいはその周辺で地下水の揚水が行われ ている地点がある. 図中の曲線に見られる細か い変動は揚水による水位の低下とその後の回復 を表している。

(3) 地下水位の上昇は降雨とよく対応している. 灌 賄期では降雨による水位の上昇も顕著である.

図-4は，灌游開始前の水位（標高で表示）につい て，2001 年 6 月 (破線) と 2002 年 6 月上旬 (実線) の結果を比較したものである. この図より，2002 年 6 月の結果は前年度の同時期のものとほぼ一致して
いること，したがって, 2002 年度の水位分布は特異 なものではないことがわかる. なお，水位の等高線 はほぼ地形の等高線に沿う形になっていること，水 位が平均海水面よりも低い地域が詰田川河口周辺に 形成されていることは，この時期に限らず年間を通 して確認される現象である.

図-5 は，6月上旬の水位に較べて 6 月下旬の水位 がどの程度上昇したかを示したものである. $1 \mathrm{~m}$ 程 度の水位上昇を示す地点が多いが，図中の黒丸で示 すように水位が低下した地点も存在する. 水位低下 は揚水が盛んに行われていることを表している.

前述のように，灌激期には農業用水として香川用 水から多量の導水が行われている. 香川用水の導入 により地下水の水位がどのように変化したかを検討 する. 図-6 は 1962 年 5 月下旬の水位 ${ }^{1}$ と今回の灌 溉開始直前の水位とを比較したものである. 図中の 実線は 1962 年での地表面から地下水面までの深さ の等值線であり，沿岸部では $1 \mathrm{~m}$ 以下，春日川・新 川周辺では $1 \sim 2 \mathrm{~m}$ 程度, 香東川右岸の扇状地では 2 $\sim 6 \mathrm{~m}$ 程度となっている. 特に, 扇央部での水位が 低く，多量の揚水が行われていたことを示唆してい る. 一方，現状での地下水面までの梁さは丸印の大 


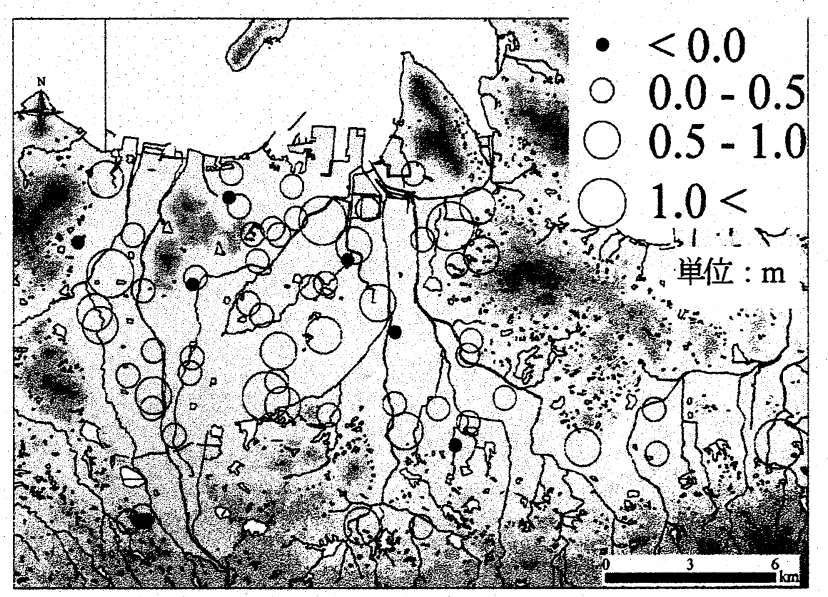

図-5 地下水位の変動量 (2002 年6月)

きさで表現されている．扇央部での水位は現在地表 面下 $2 \mathrm{~m}$ 程度の地点が多く，かつてより水位がかな り上昇していることがわかる. 一方, 沿岸部での水 位を比較すると，地下水面までの梁さが増大してい ることが知られる. すなわち, 現在の高松地域全体 では，上下流部間での地下水面の差が以前より大き くなり，地下水が流れやすい状況にあると判断され る. 水位変化の原因として, 扇央部では香川用水に よって地下水を揚水する必要性が低下し，揚水量が 抑制されたためであると推測される. 沿岸部では不 浸透域の増大により雨水浸透が抑制された可能性が ある. ただし，上流部では早場米の作付けを行うた めに水田に水を張る時期がかつてより早くなってい る地域もあり，それによって 6 月上旬の水位が上昇 する可能性については検討が必要である. なお， 9 月下旬の水位を比較すると, 香川用水導入以前と現 在との差異は小さいことがわかっている.

図一7 は 6 月上旬から 7 月中旬までの水位の連続 観測結果（地表面からの深さで表示）を示したもの である. 灌䄽期はじめにおいて水位は緩やかに増加 している. また，まとまった降雨を受けて段階的に 水位が上昇していく，なお，降雨に対する水位応答 は特徴がある. 河川に近接していたり斜面の下に位 置する地点 67 (図-1)，R，U（図-2）では水位の立 ち上がりや莪減が明瞭である. 扇状地の水ミチ上に 位置すると考えられる地点 $50,52, \mathrm{~K}, \mathrm{G}$ (図-2) では変化が穏やかであるが，まとまった降雨に対す る応答は早い.

\section{（1）地下水の水質}

\section{a) $\mathrm{pH}$}

6 月上旬, 6 月下旬および 9 月中旬における地下水 の $\mathrm{pH}$ の測定結果を図-8 に示す． 6 月から 9 月にな るにつれて, pH の分布特性はあまり変化しないが, 酸性から中性に変化する傾向が確認できる.

b）ヘキサダイアグラムとクラスター分析

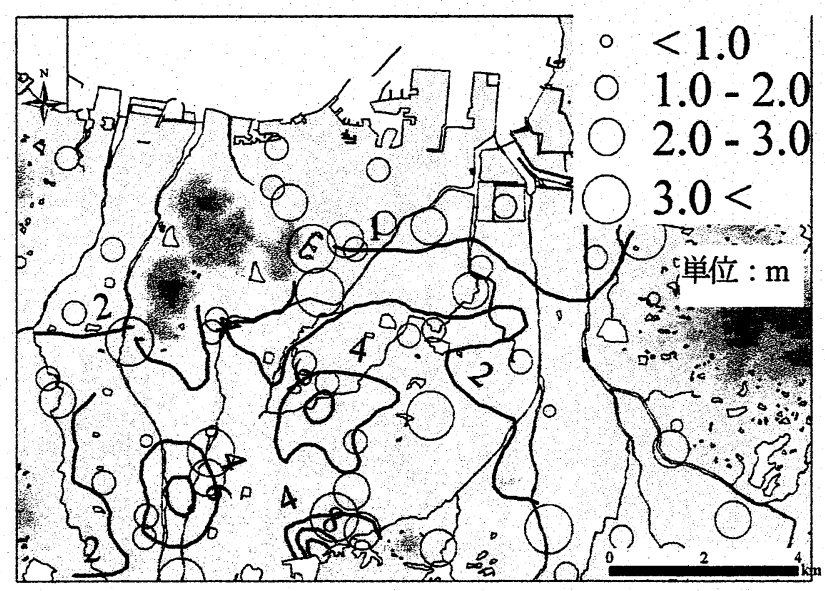

図-6 香川用水導入以前と現在の灌漞前の地下水位の比較

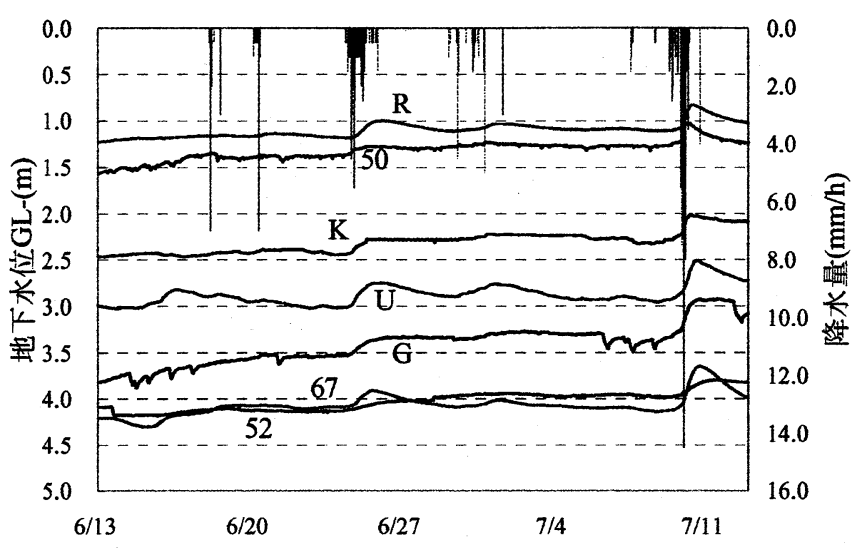

図-7 灌㿞期における地下水位変動

図-9は6月上旬と下旬における地下水中の各種イ オンの分析結果を基に作成したへキサダイアグラム である. へキサダイアグラムの下の数字は井戸番号 である. 図より, 殆どの地点において，その形，大 きさは安定しており，経時的な変化は小さいことが わかる.

ヘキサダイアグラムの作成に用いた各種イオン濃 度を変数として 6 月上旬, 下旬, 9 月の分析結果に ついてクラスター分析 (距離の計算 : ウォード法) を行い，水質を 4 つのグループに分類した. その結 果を図-10(a)，(b)，（c)に示す。また，表-1には各 群の平均的なイオン組成を示している. それぞれの 群の特徴は次のように要約できる.

- 1 群:4つの群の中で最も所属する個体数が多く, 高松平野全体に分布している. 平野南部の井戸 のほとんどがこの群に属する. 卓越イオンがあ るのではなく，どれも量的に少ない，

- 2 群 : 1 群の次に属する個体数が多い. 高松平野 北部に多く見られる. $\mathrm{Ca}^{2+}$ と $\mathrm{HCO}_{3}{ }^{-}$が多い. 経 時的に 1 群と 2 群の間で变化する地下水が 7 地 点存在する.

- 3 群 : この群に属する地点は少なく, 沿岸部に 位置する井戸 (4 番, 94 番) が属している. 成 

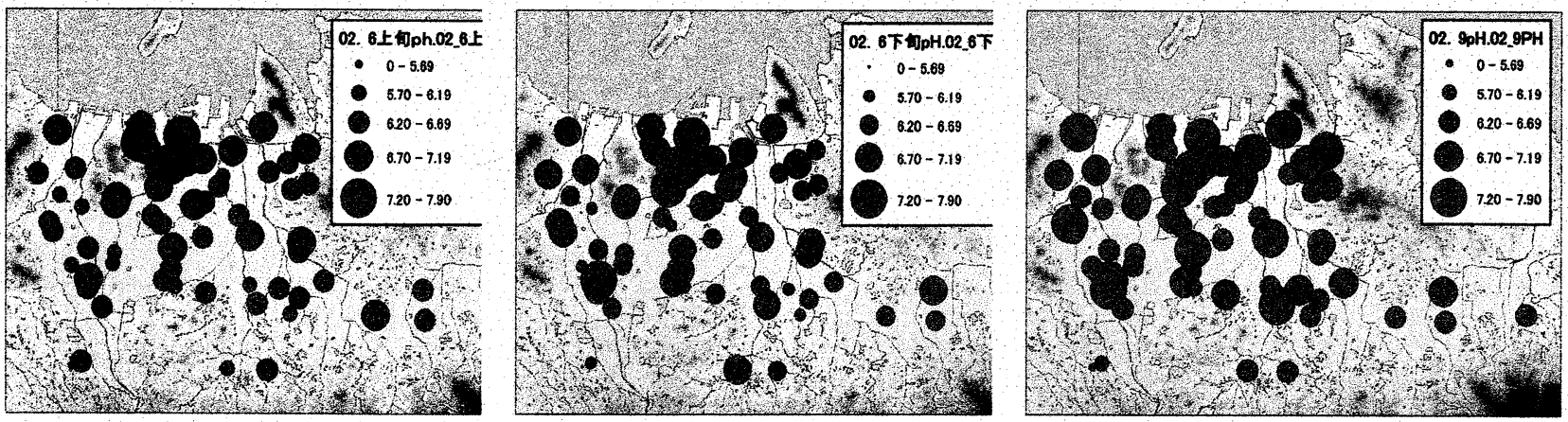

图-8 pH（左加 6月上旬，6月下旬，9月中旬）

分には $\mathrm{Na}^{+}, \mathrm{K}^{+}, \mathrm{Cl}^{-}$が多 い. ヘキサダイアグラム と照らし合わせてみると， この群には海水の混入が ある地下水が属している. 4 群 : ヘキサダイアグラ ムで見ると, イオン量が 比較的多く, 硝酸イオン 濃度が高い地下水が属し ている. まれに 1,2 群に 属した地下水が一時的に 4 群に属することがある. 実際に 4 群に属する井戸で は，硝酸性窒素が環境基準で ある $10 \mathrm{mg} / 1$ を超えている. 周 辺の土地利用から 48 番の井 戸では施肥と畜産が污染原因 となっており，また他の地点 でも人為的影響により一時的 に硝酸イオン濃度が高くなっ ているものと考えられる。

図-10より，3 時期におい て属する群が変化する地点は あるが，その原因としては地 下水位の変化の影響というよ りも海水浸入や施肥などの影 響と判断される. なお, 5 群 に分類した場合には上記の 4 群がさらに $2 つ に$ 細分される.

属性分類の要因となって いるイオン成分を調べるため に, 主要イオン成分でなくク ラスター分析の結果を用いて 判別分析 (変数増堿法) を行 った. 表-2に判別分析の主た る結果を示す. イオンの横に 表示されている数字は判別係 数である. この表よりほとん どのグループ分けで陰イオン

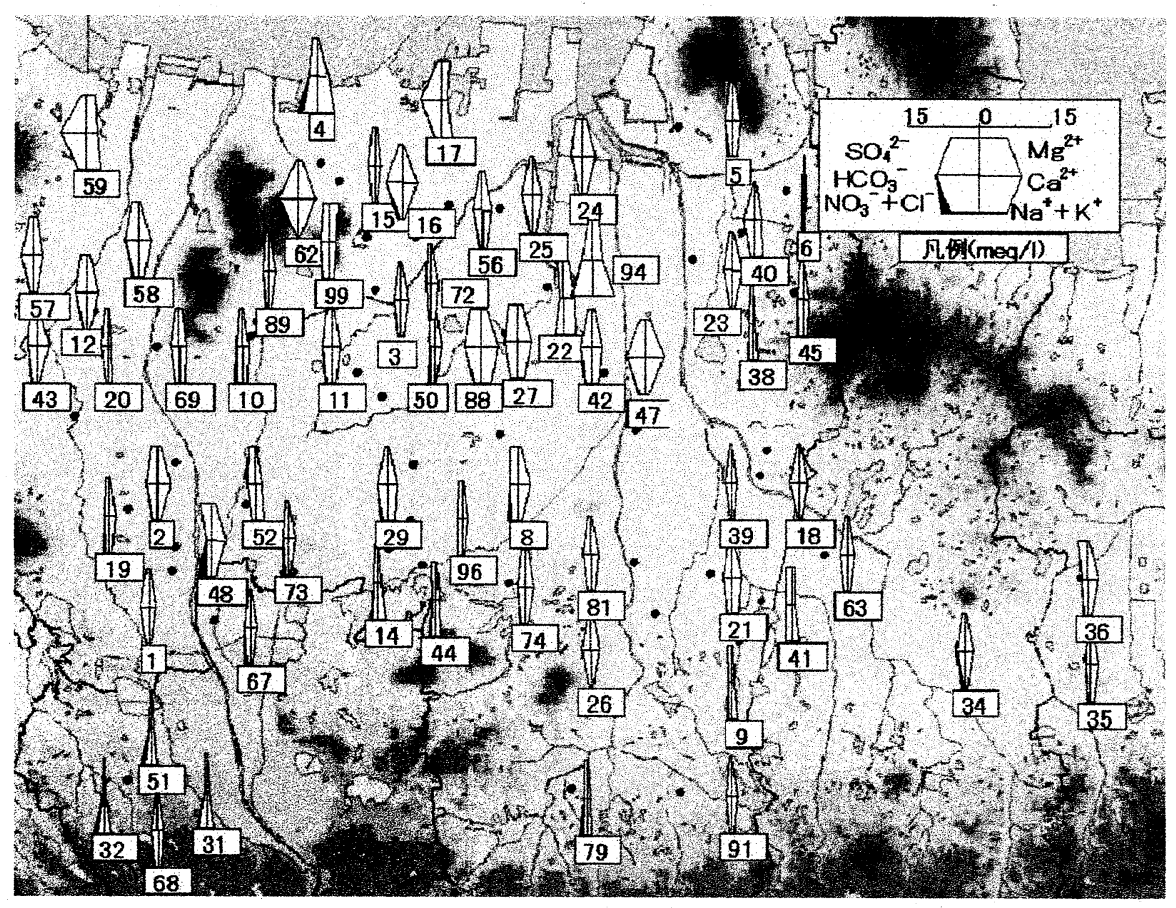

図-9（a） ヘキサダイアグラム（6 月上旬）

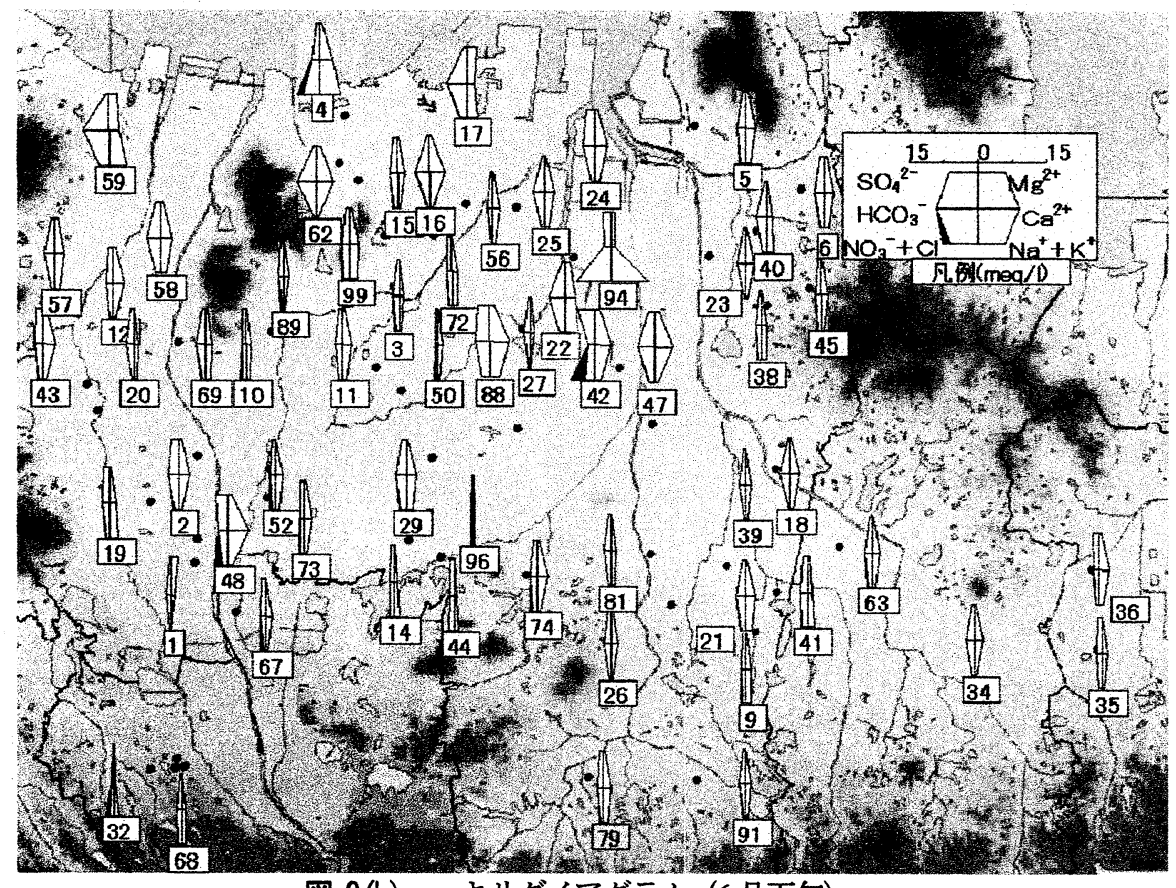

図-9(b) へキサダイアグラム（6月下旬） 

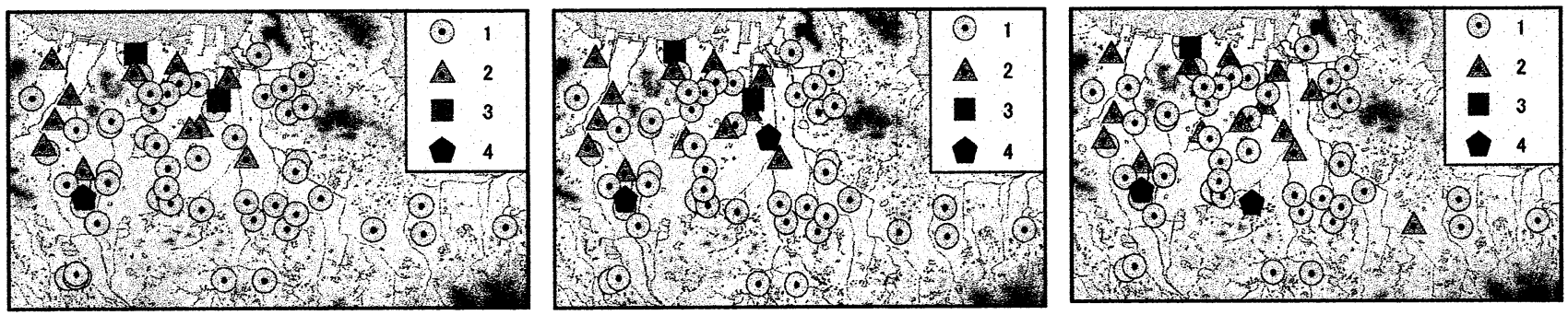

図-10 クラスター分析による水質からみた分類（左から6月上旬，6月下旬，9月中旬）

表-1＼cjkstart各群のイオン組成（平均值）（meq/1）

\begin{tabular}{|c|c|c|c|c|c|}
\hline & 全体 & 群 1 & 群 2 & 群 3 & 群 4 \\
\hline $\mathrm{SO}_{4}^{2-}$ & 0.75 & 0.64 & 1.11 & 0.95 & 261 \\
\hline $\mathrm{HCO}_{3}^{-}$ & 1.69 & 1.28 & 3.03 & 1.69 & 2.20 \\
\hline $\mathrm{Cl}^{-}$ & 0.69 & 0.62 & 0.92 & 4.29 & 1.45 \\
\hline $\mathrm{NO}_{3}^{-}$ & 0.17 & 0.19 & 0.11 & 0.64 & 154 \\
\hline $\mathrm{Mg}^{2+}$ & 0.52 & 0.39 & 0.96 & 0.76 & 1.28 \\
\hline $\mathrm{Ca}^{2+}$ & 1.83 & 1.48 & 2.97 & 1.97 & 4.75 \\
\hline $\mathrm{Na}^{+}+\mathrm{K}^{+}$ & 0.97 & 0.88 & 1.28 & 4.66 & 1.23 \\
\hline
\end{tabular}

が関与していることがわかる.

\section{5. まとめ}

高松地域における 65 箇所の井戸の一斉測水, 水質 分析, および水位の連続観測から, 灌溉用水の導入 が不圧地下水の水位や水質に及ぼす影響を考察した. その結果，次のことが明らかとなった。

1. 灌溉期には水位はしだいに上昇するが，その 変化のパターンは降水や立地地点, 揚水に依 る.

2. 香川用水の導入以前と現在を地下水位につい て比較すると，灌泊開始前より現在の方が扇 央部で高く, 沿岸部で低くなっている. その 原因として扇央部では揚水量の減少が, 沿岸 部では降雨による涵養量の減少が考えられる。

3. 灌激期には地下水の酸性側の $\mathrm{pH}$ が中性に近 づく.

4. ヘキサダイアグラムに基づき判断すると, 灌 溉の前後で水質が変化する地点は限られてい る. また, 変化の要因として施肥などの人為 的な要因と潮汐のような自然的な要因が考え られる.

5. ヘキサダイアグラムで用いたイオン濃度を使 用したクラスター分析によると, 高松地域の 不圧地下水は 4 群に分類できる.
表-2 判別分析結果

\begin{tabular}{|c|c|c|c|}
\hline & 群 1 & 群 2 & 群 3 \\
\hline \multirow{3}{*}{$\begin{array}{c}\text { 群 } \\
2\end{array}$} & $\mathrm{NO}_{3}{ }^{-}(-7.08)$ & & \\
\hline & $\mathrm{HCO}_{3}^{-}(-4.27)$ & & \\
\hline & $\mathrm{SO}_{4}^{2-}(-3.92)$ & & \\
\hline \multirow{3}{*}{$\begin{array}{c}\text { 群 } \\
3\end{array}$} & $\mathrm{NO}_{3}{ }^{-}(-24.31)$ & $\mathrm{NO}_{3}{ }^{-}(-34.31)$ & \\
\hline & $\mathrm{Cl}(-16.8)$ & $\mathrm{SO}_{4}^{2-}(15.79)$ & \\
\hline & - & $\mathrm{Cl}^{-}(-12.37)$ & \\
\hline \multirow{3}{*}{$\begin{array}{c}\text { 群 } \\
4\end{array}$} & $\mathrm{NO}_{3}^{-}(43.99)$ & $\mathrm{NO}_{3}^{-}(-25.2)$ & $\mathrm{HCO}_{3}^{-}(22.89)$ \\
\hline & $\mathrm{SO}_{4}^{2-(-12.52)}$ & $\mathrm{Ca}^{2+}(-6.77)$ & $\mathrm{Ca}^{2+}(-14.45)$ \\
\hline & $\mathrm{Ca}^{2+}(-10.3)$ & - & $\mathrm{Mg}^{2+}(-13.28)$ \\
\hline
\end{tabular}

謝辞 : 本研究の実施に際して, (財) 香川県科学技術 振興財団の産学官共同研究開発事業 (代表者 : 吉野 文雄) およひ科学研究費補助金基盤研究(C)(2)（代表 者 : 河原能久) の援助を受けた.ここに記して謝意 を表します．また，データを提供いただいた国土交 通省香川工事事務所に感謝いたします。

\section{参考文献}

1) 東京教育大学地理学教室: 高松平野およひ綾川流域におけ る水の賦存量に関する地理学的研究，p.229, 1965.

2) 新見 治:泉と地下水, 地学雑誌, Vol. 98, No.2, pp. 111-127, 1989.

3）河原能久, 渡邉健一, 森長和雄 : 高松地域における地下水 環境の観測，水工学論文集，第 46 巻, pp.211-216, 2002.

4) 井伊博行, 平田健正, 加々美久夫 : 松本市周辺の水質と土 地利用について, 水工学論文集, 42 巻, pp.373-378, 1998.

5) 藤原 拓，大年邦雄，唐 心強，山辺敬介：沿岸施設園芸 地帯における地下水水質の多変量解析による類型化に関す 万研究，水環境学会誌，第 24 巻，724-732，2001.

6）谷川晋一：無機水質組成を用いた扇状地地下水の流動分析 について, 水文・水資源学会 2002 年研究発表会要旨集, 60-61, 2002.

7) 高橋 学: 高松平野の地形環境一弘福寺領山田郡田図比定 地付近の微地形環境を中心に一, 頶岐国弘福寺領の調查一 興福寺領贊岐国山田郡田図調查報告書一」, pp.149-192，高 松市教育委員会, 1992.

(2002. 9. 30受付) 